\&o

Marilucia Ben*

\section{O trabalhador do campo e da cidade na lógica do capital} agroindustrial: Santa Catarina e Paraná

Resumo: Esse trabalho busca entender de forma abrangente as relações de qualificação/desqualificação através da Educação (in) formal, voltada para o capital/consumo com vistas ao agronegócio. Trata-se de dois trabalhos unidos pela correlação, sendo um voltado para a região Oeste de Santa Catarina e o outro para o Oeste do Paraná, que por ocasião, têm como base à dependência de grandes grupos econômicos agroindustriais, como a BRF (Brasil Foods) e Aurora em Chapecó (SC), Diplomata S/A Industrial e Comercial em Xaxim (SC), e Cooperativa Agroindustrial Lar em Medianeira (PR), essas empresas e cooperativas, dominam o setor de carnes de aves/suínos e seus derivados. Na relação entre o campo/cidade/agroindústria, o trabalhador da cidade e do campo (integrado), vêm constantemente se qualificando/desqualificando para atender aos interesses da (re) produção do capital, impostas pelos complexos agroindustriais e também às exigências do mercado internacional. Ao mesmo tempo em que o trabalhador se qualifica/desqualifica, vive processos contraditórios e de confronto nas relações sociais de produção. Sendo assim o capital ao exigir maior escolarização do trabalhador, simplifica sua atividade, o torna flexível e polivalente, desenvolvendo a pedagogia das habilidades e competências, maximizando a extração da mais valia e submetendo-o ao ritmo da máquina e da produção. Compreender como as famílias integradas/associadas e também os trabalhadores da agroindústria são escolarizados para atender os interesses do capital agroindustrial da região Oeste catarinense e paranaense, é o objetivo geral do trabalho. A área de estudo compreende os municípios de Xaxim e Chapecó no Oeste de Santa Catarina e Medianeira no Oeste do Paraná, caracterizados pela forte presença agroindustrial, além do significativo setor de comércio e serviços, voltados em parte para atender as demandas das agroindústrias. O período pesquisado data entre 1960 a 2010, caracterizado por profundas transformações no campo e na cidade, resultado da reestruturação produtiva entre capital/trabalho.

\section{The rural and city workers in the logic of agribusiness capital: Santa Catarina and Paraná}

\footnotetext{
Abstract: This article seeks to understand the relations of qualification/disqualification through Education (in) formal, facing the capital/consumption with a view to agribusiness. These are two works together by correlation, with one facing the West of Santa Catarina and the other to the West of Paraná, which at the time, are based on the dependence of large agribusiness conglomerates such as BRF (Brazil Foods) and Aurora in Chapecó (SC), Diplomat S/A Industrial and Commercial in Xaxim (SC), and Cooperativa Agroindustrial Lar in Mediatrix (PR), these companies and cooperatives dominate the meat sector of chicken / pork and its derivatives. In the relationship between the rural / urban / agricultural industry, the employee of the town and country (integrated), are constantly qualifying / disqualifying to meet the interests of (re) production of capital, imposed by agro-industrial complex and also the demands of the international market. While the worker qualifies / disqualifies lives contradictory and confrontation in social relations of production processes. Thus the capital to demand higher education worker, simplifies its activity, makes it flexible and versatile, developing the pedagogy of skills and competencies, maximizing the extraction of surplus value and subjecting it to the rhythm of the machine and production. Understanding how families integrated / associates and also the agribusiness workers are educated to meet the interests of agribusiness capital of Santa Catarina and Paraná West, is the general objective of the work. The study area comprises the municipalities of Xaxim and Chapecó in western Santa Catarina and Mediatrix in western Paraná, characterized by strong agribusiness presence, in addition to significant trade and services sector, aimed in part to meet the demands of agribusinesses. The research period date between 1960 to 2010, characterized by profound changes in the field and in the city, the result of productive restructuring of capital/labor.
}

Valdir Skrzypczak**

Marli Terezinha Szumilo Schlosser***

Carmen Rejane Flores Wizniewsky****

* Mestre em Geografia pela Universidade do Oeste do Paraná (UNIOESTE). Doutoranda em Geografia na Universidade Federal de Santa Maria (UFSM).

** Mestre em Geografia pela UNIOESTE (Campus Francisco Beltrão). Professor na Secretaria Municipal de Xaxim (SC).

*** Doutora em Geografia pela Universidade Estadual Paulista Julio de Mesquita Filho (UNESP).

**** Doutora em Geografia e Ciências do Território pela Universidade de Córdoba (UCO, Espanha). Professora Adjunta no Departamento de Geociências da UFSM.

Palavras-chave:

Trabalho; educação; precarização cidade; campo; agroindústria.

Key-Words:

Work; education; insecurity; city; field; agribusiness.

1 Esse trabalho é resultado de estudos coletivos de integrantes do Laboratório de Ensino de Geografia (LEG) em parceria com as Universidades - UNIOESTE e UFSM, orientado e debatido pelas docentes Marli Terezinha Szumilo Schlosser e Carmem Rejane Flores Wizniewsky.

Geografia Ensino \& Pesquisa, vol. 18, n. 3, set./dez. 2014. 


\section{Introdução}

Inicialmente cabe destacar que o texto é resultado de pesquisas que estão sendo realizadas no âmbito do Grupo de Estudos vinculadas à linha de pesquisa Educação e Ensino de Geografia da Universidade Estadual do Oeste do Paraná (Unioeste) Paraná, e Produção Do Espaço E Dinâmicas Territoriais da Universidade Federal de Santa Maria (UFSM) - Rio Grande do Sul. A pesquisa envolve docentes e discentes da pós-graduação, das referidas universidades, num movimento de reflexão e debates, sobre aspectos das relações de qualificação/desqualificação a partir da Educação (in) formal, voltada para o capital/consumo com vistas ao agronegócio. Trata-se de dois trabalhos unidos pela correlação, sendo um voltado para a região Oeste de Santa Catarina e o outro para o Oeste do Paraná, que por ocasião, têm como base à dependência de grandes grupos econômicos agroindustriais, como a BRF (Brasil Foods) e Aurora em Chapecó (SC), Diplomata S/A Industrial e Comercial em Xaxim (SC), e Cooperativa Agroindustrial Lar em Medianeira (PR), sendo empresas e cooperativas que dominam o setor de carnes de aves/suínos e seus derivados.

Nesse sentido, com a pesquisa proposta e na busca de identificar e explicitar aspectos teóricos deste processo torna-se relevante entender a relação entre o campo/cidade/agroindústria, que acaba por tornar o trabalhador da cidade e do campo (integrado), qualificado/desqualificado para atender os interesses da (re) produção do capital, impostas pelos complexos agroindustriais e também às exigências do mercado internacional. No movimento da reprodução capitalista o trabalhador se qualifica/ desqualifica, vive processos contraditórios e de confronto nas relações sociais de produção, que serão detalhadas no decorrer do texto.

Portanto, as áreas da pesquisa são dominadas pelas agroindústrias de carnes, como a Brasil Foods, Aurora, Diplomata S/A Comercial e Industrial e Cooperativa Agroindustrial Lar que compõem a estrutura regional voltada às atividades do agronegócio, desenvolvida respectivamente no Oeste de Santa Catarina e Oeste do Paraná. Esses complexos agroindustriais dominam o setor de carnes de aves/suínos e seus derivados. A área de estudo compreende o município de Xaxim e Chapecó no Oeste Catarinense e Medianeira no Oeste Paranaense. O período de estudos datam entre 1960 a 2010, caracterizado por transformações no campo e na cidade, que busca a reestruturação da produção que acaba modificando as relações sociais, políticas e econômicas entre o capital, trabalho e sociedade.

$\mathrm{Na}$ tríade da relação dialética entre campo/cidade/agroindústria, o trabalhador do campo e da cidade constantemente vem se qualificando/desqualificando para atender às exigências de produção e relações de produção impostas pelo capital agroindustrial. Ao mesmo tempo em que se escolariza, o trabalhador vive processos contraditórios e de confronto nas relações de produção, "momentos de educação e de deseducação, de qualificação e de desqualificação, e, portanto, de humanização e de desumanização". (KUENZER, 2011, p. 11). O cooperativismo empresarial, bem como as agroindústrias discursivamente apresentam-se como principais instrumentos para promoção do desenvolvimento econômico e social de seus associados/cooperados/integrados/trabalhadores, desenvolvendo camponeses passivos de Projetos Sociais Educativos para a doutrinação e aplicação de seus princípios, com cursos para associados de cooperativas e empresas agroindustriais. São esses projetos que visam doutrinar seus associados/ cooperados/ integrados/ trabalhadores disseminando princípios que nem sempre são compatíveis com a educação emancipadora, desenvolvendo, em contrapartida, prejuízos em relação à liberdade e emancipação intelectual da sociedade, portanto, está pautada na formação de mão de obra dependente do setor agroindustrial, na especialização da produção e consumo em massa. 


\section{Educação/precarização do trabalhador do campo e da cidade, na lógica do capital agroindustrial.}

As novas relações de produção têm início com a chegada das empresas colonizadoras no Oeste de Santa Catarina e Oeste do Paraná. Em Santa Catariana a partir de 1920 introduziram a comercialização de pequenos lotes de terra, aos colonos vindos do Rio Grande do Sul e a consequente expulsão de índios e caboclos da região. Para Alba (2002), "O modo de produção capitalista já havia estabelecido relações de dominação e de seccionamento das unidades produtivas em outros locais do país e do mundo" e as forças que buscavam Chapecó e região eram excedentes populacionais do Rio Grande do Sul, trazidas pelas empresas colonizadoras, que na região Oeste de Santa Catarina buscavam "[...] novas maneiras de viver e sobreviver, dentro de um modo de produção velho que já apresentava suas contradições internas de destruição" (ALBA, 2002 p. 29). Nesta lógica a terra deixava de ser natureza e produção de alimentos para as famílias, para ser transformada em capital. Era um bem coletivo que passou a ser objeto de compra e venda para produzir renda e riqueza às empresas colonizadoras e posteriormente as agroindústrias.

A colonização do Oeste do Paraná ocorrida após 1940 no contexto da política e da geopolítica da Marcha para o Oeste objetivava, a partir das empresas colonizadoras, explorar a madeira, mercantilizar as terras, abrir novos ramos do comércio e à indústria (GREGORY, 2002). No que tange a comercialização de terras, as mesmas eram baseadas na pequena propriedade familiar, priorizando colonos descendentes de europeus do Rio Grande do Sul e de Santa Catarina, que já estavam habituados à atividade agrícola colonial. Este planejamento visava a industrialização da agricultura, devido aos acontecimentos em que o País estava inserido após a Segunda Guerra Mundial.

O Oeste do Paraná era visto pelo poder público como grande potencial para ampliar a fronteira agrícola, mesmo sendo a região habitada por povos indígenas que viviam da coleta e da caça. A Igreja, o governo de Estado e a empresa colonizadora estabelecida para se apropriaram do espaço, concreta (pelas rodovias, ferrovias, comércio) e abstratamente (pela língua, informação, ideologias, leis), efetivavam a ocupação da fronteira, (re)produzindo relações de poder.

Tanto no Oeste de Santa Catarina como no Oeste do Paraná os índios e caboclos foram expulsos ou excluídos do processo de produção, “[...] Devido às suas relações de produção primitivas, nada mais tinham a oferecer [...]” (ALBA, 2002 p. 29) ao capital, diferentemente dos agricultores que aí se instalaram e estabeleceram [...] "um tipo de propriedade diferente das anteriores.” [...] (Idem, p. 29), adaptando-se às novas formas de produzir e comercializar impostas pelo capital. Nas pequenas propriedades do Oeste de Santa Catarina e do Paraná, empresas e cooperativas tem atuado para o desenvolvimento de novos modos de produção e o excedente passa a ser comercializado com centros maiores, como São Paulo e Porto Alegre, servindo como intermediários dessa comercialização. Com a ampliação dos negócios, esses pequenos grupos de comerciantes, gradativamente implementaram o uso de modernas técnicas e também de novas atividades como a avicultura e a suinocultura.

A educação não formal tem influenciado de maneira significativa nas novas formas de produção do campo no Oeste de Santa Catarina e do Paraná, a partir das empresas e cooperativas agroindustriais, como já mencionados. Para Gadotti (1998), "Os campos de ação da educação popular comunitária podem ser tanto a escola formal, como a não-formal, as organizações econômicas e populares, as escolas produtivas e mesmo as microempresas" (GADOT'TI, 1998 p. 307). O cooperativismo do Oeste do Paraná, atua nas duas formas de educação apresentada, tanto formal como não-formal, pois, as cooperativas que atuam no Oeste paranaense como Lar, Coopavel, Copagril entre outras dispõe de cursos para capacitar a formação de seus associados, formando mão-de-obra para o desenvolvimento de suas atividades como: gado leiteiro, avicultura, suinocultura, apicultura entre outros.

Geografia Ensino \& Pesquisa, v. 18, n.3 p. $37-54$, set./dez. 2014

Ben, M.; Skrzypczak, V; Schlosser, M.T.S.; Wizniewsky, C.R.F.

ISSN 2236-4994 
A área de abrangência e localização da Cooperativa Agroindustrial Lar, que está situada no município de Medianeira/PR (Figura1).

Figura 1 - Localização das áreas de atuação da Cooperativa Agroindustrial Lar.

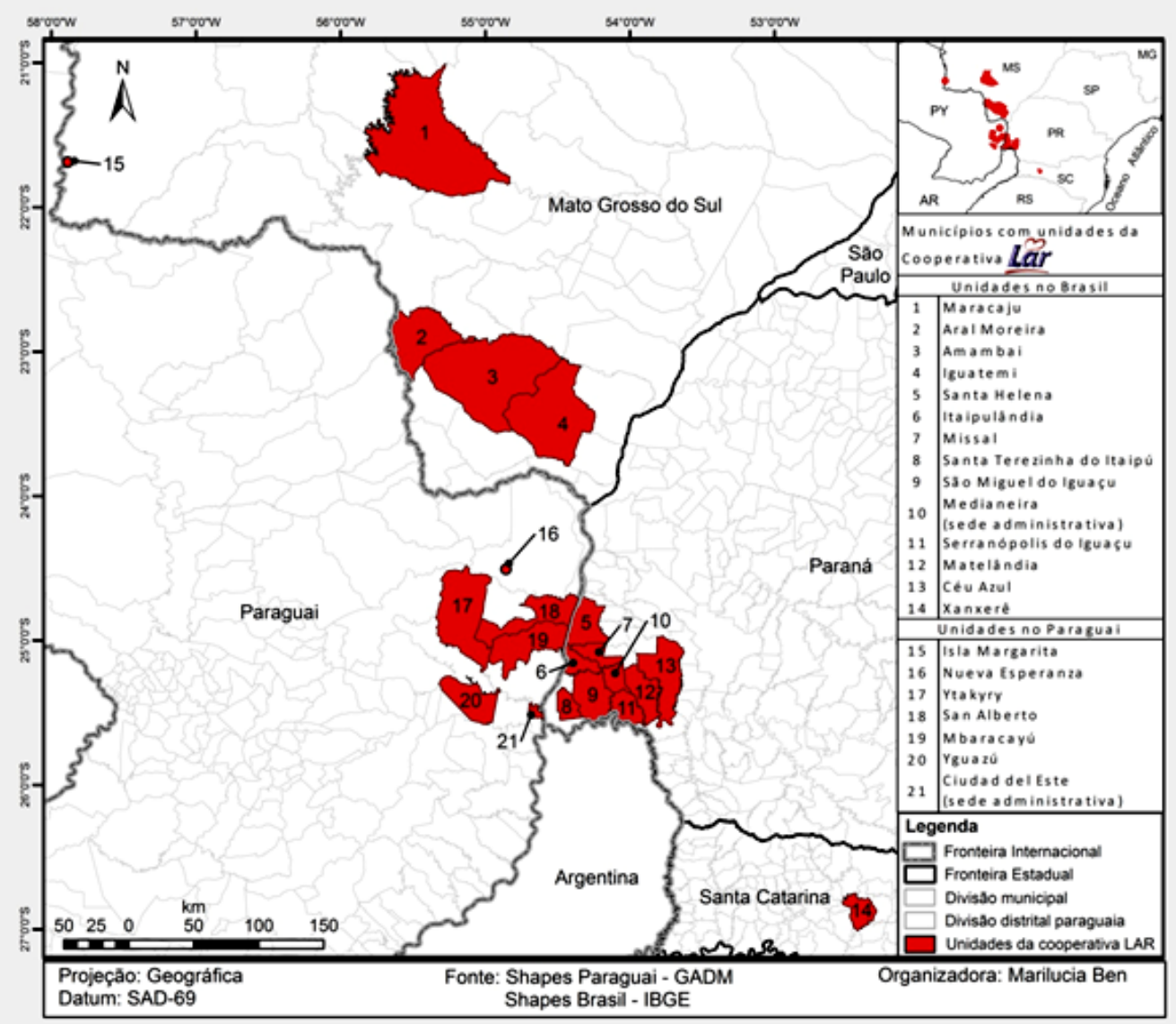

Fonte: Elaborada por Marilucia Ben.

Atualmente a Cooperativa Agroindustrial Lar conta com redes de supermercados, unidades industriais de vegetais, de leitões, de aves, de pintinhos, de ração, de mandioca, de soja e posto de combustível. Isso a torna "poderosa" financeiramente no mercado do Oeste paranaense, pois, além de receber as matérias-primas dos associados, faz seu beneficiamento, agregando valor ao produto, nos diversos segmentos já citados. Essa estrutura modificou o território paranaense, que a partir da relação com o capital agroindustrial ampliou a expropriação das propriedades e modificou a forma de produzir. As propriedades rurais que não atenderam ao sistema agroindustrial e os camponeses que não modificaram seu modo de produzir, em sua maioria foram extintos do meio rural. Portanto, os camponeses associados mudaram sua vida cotidiana para atender as novas relações de produção e trabalho. As formas de produção estão voltadas para a padronização de alimentos criados

Geografia Ensino \& Pesquisa, v. 18, n.3, p. $37-54$, set./dez. 2014

O trabalhador do campo e da cidade na lógica do capital agroindustrial: Santa Catarina e Paraná artificialmente e combinados para atender metas de produtividade. As propriedades rurais acabam por receber essas novas formas de produzir e aos camponeses resta trabalhar em aviários, chiqueirões, gado leiteiro, com as implementações exigidas pelo agronegócio. Além de atuar no Oeste paranaense, a empresa possui unidades no Mato Grosso do Sul, em Santa Catarina e no Paraguai. O fluxo de pessoas e de mercadorias tem aumentado, juntamente com o crescimento industrial da cooperativa. Intensificada na década de 1990, a agroindustrialização da cooperativa Lar proporcionou o aumento de suas atividades em outras regiões nacionais e internacionais (no Paraguai). 
Ao fazer referência ao cooperativismo, mais do que reforçar o que vem sendo disseminando como "movimento cooperativista", se propõe as amplas reflexões do significado do trabalho coletivo para a humanidade.

O cooperativismo teve suas origens no século XVIII e XIX na Europa, especialmente na Inglaterra e na França. Servia como defesa de trabalhadores excluídos do mercado de trabalho em consequência da Revolução Industrial, que estruturou o capitalismo, (re) produzindo as categorias dominante/dominado. Surgiu como sistema formal caracterizado por relações simples que serviam para organizar os grupos sociais, com objetivos e interesses comuns, amparado nos princípios de ajuda mútua e de controle democrático da organização pelos seus membros, nesse caso desenvolvendo o caráter de proprietário/ usuário por seus associados. (SCHNEIDER, 1981).

Com as territorialidades do capitalismo e o desenvolvimento do agronegócio o cooperativismo passou a ser configurado como alternativa dentro do sistema e não mais como alternativa ao sistema (SERRA, 1986). A lógica desigual/contraditória/combinada do agronegócio também rege as relações capitalistas de produção, pois, desenvolve o aumento da produção, da exploração, do homem e da natureza, consequentemente aumenta a produção da mais-valia e concentra/acumula/amplia o capital, ampliando as desigualdades sociais. Neste sentido o movimento cooperativista levou à constituição de cooperativas especializadas, dentro do sistema capitalista de produção/agronegócio, e ali, segundo Pinho (1982), foi sendo tendência do seu desvirtuamento, isso em decorrência de problemas resultantes da própria "evolução" da cooperativa, que deixou de ser simples associação mutualista para se transformar em complexa organização social, incorporando os problemas da empresa capitalista moderna.

A incorporação dessa complexa organização social, dentro do sistema apresentado reflete na inserção do camponês no mundo do trabalho, sob os ditames do capital. De acordo com Oliveira (1990), quando o camponês é submetido aos ditames do sistema capitalista/agronegócio, sujeita à renda da terra ao capital. O trabalho excedente do camponês e sua família vão sendo convertido em renda capitalista. Nesse sistema a cooperativa/ agroindústria acaba por se apropriar da renda da propriedade camponesa sem ser proprietário e produzindo capital por relações não capitalistas, pois, o camponês compra os produtos e insumos, assume todos os riscos da produção, que são estruturas do Complexo agroindustrial. A cooperativa/agroindústria assume o papel de provedora do lucro e desenvolve o sistema de competividade, metas de produtividade, para incentivar o camponês a produzir mais e melhor para o acúmulo de capital. São promovidos concursos de produtividade pela cooperativa/agroindústria, entre associados/camponeses/integrados, que premeia com eletro portáteis para quem atingir maior produtividade nas propriedades. Este mecanismo favorece o desempenho e aumento da produção e a competividade dentro do cooperativismo, promovendo o desvirtuamento. Segundo Schlosser (2005) o sistema cooperativista, neste caso, foi desenvolvido para organizar/ampliar os negócios pertinentes à comercialização dos produtos agrícolas e acaba por incentivar a especialização da produção com cultivos de produtos do agronegócio, reorganizando a produção das propriedades rurais, através de créditos, assistência técnica e a comercialização dos produtos.

Já no Oeste de Santa Catarina o trabalhador da agroindústria e o camponês familiar integrado vêm constantemente se qualificando/desqualificando para atender as exigências do capital agroindustrial, pois com a introdução de novas tecnologias no processo produtivo o trabalho simplifica-se, porém o trabalhador busca ampliar o grau de escolaridade através da Educação de Jovens e Adultos (EJA) e dos cursos profissionalizantes oferecidos pelo Serviço Nacional de Aprendizagem Industrial (SENAI) em parceria com a agroindústria, na modalidade menor aprendiz, onde adolescentes a partir dos 16 anos são selecionados para o curso de técnico em alimentos, sendo inseridos após a conclusão como Geografia Ensino \& Pesquisa, v. 18 ,
n.3 p. $37-54$, set./dez. 2014

Ben, M.; Skrzypczak, V; Schlosser, M.T.S.; Wizniewsky, C.R.F. 
mão de obra para a agroindústria. Aos trabalhadores integrados do campo "cada vez mais é exigida educação e cultura para manter a competitividade, num mercado que se globaliza progressivamente" (TESTA et al, 1996 p. 77), com a introdução de novas tecnologias de mecanização e automatização de aviários e chiqueirões. Isso ocorre no município de Xaxim, localizado no Oeste de Santa Catarina onde atua a agroindústria Diplomata S/A Comercial e Industrial, como mostra a Figura 2.

Figura 2-Mapa da expansão territorial da agroindústria Diplomata no Brasil.

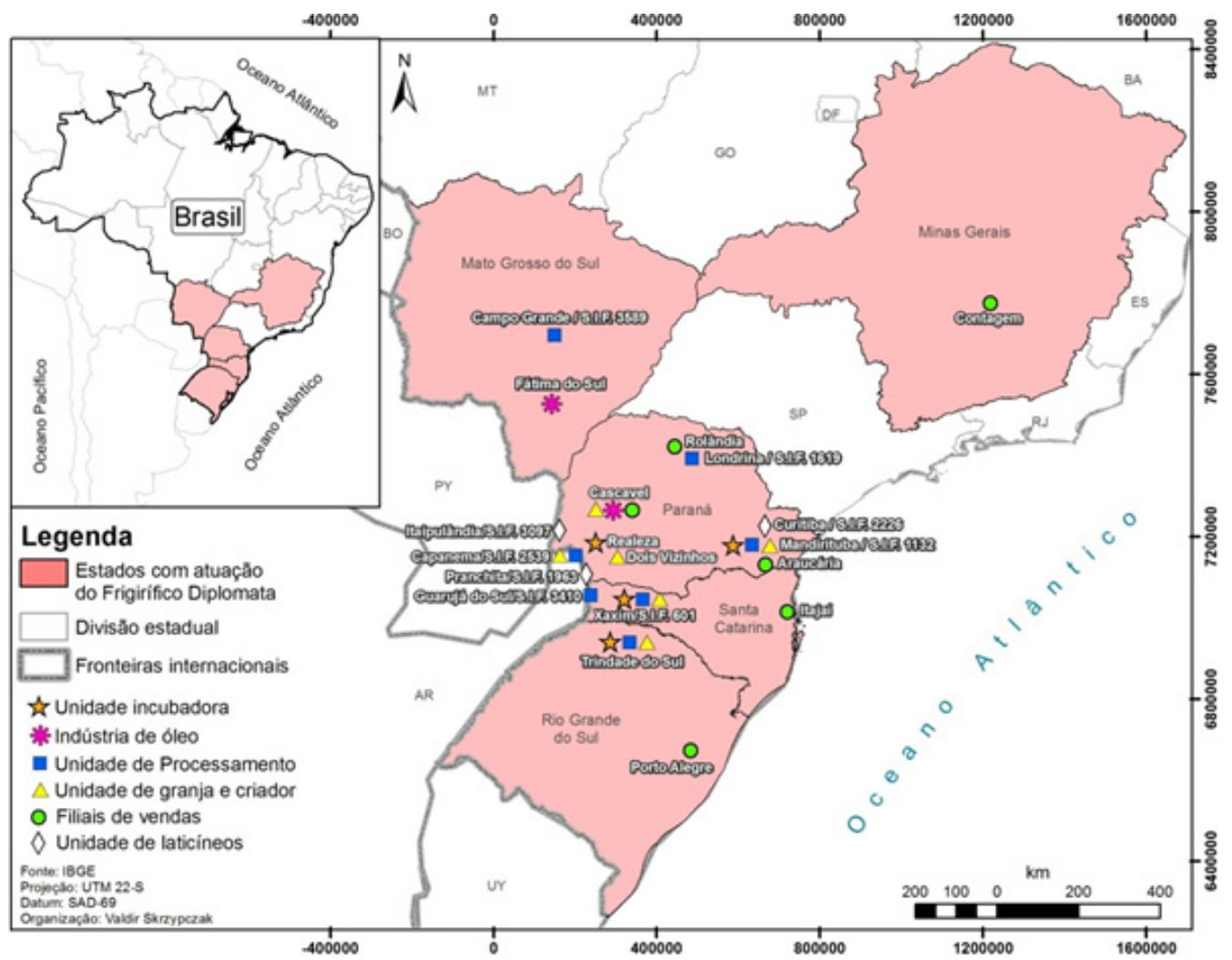

Fonte: Elaboração de Valdir Skrzypczak.

A indústria Diplomata forma um complexo agroindustrial, que conta com unidades de processamento de leite, produção de óleo vegetal de soja, granjas, incubatórios para a produção de pintinhos, além de indústrias de processamento de carne de aves. Compra a matéria-prima (frango) dos camponeses familiares integrados e abate, agregando valor comercial para a venda nos mercados nacional e internacional. Com a modernização do processo produtivo no interior da agroindústria e no campo, trabalhadores e camponeses familiares integrados buscam ampliar a escolarização formal, porém permanecem na condição de trabalhadores assalariados do capital agroindustrial. Ampliam a escolarização, ao passo que as atividades produtivas simplificam e tornam-se parciais aos trabalhadores, pois o domínio do processo produtivo como um todo se encontra com o capital.

A agroindustrialização da região Oeste de Santa Catarina é caracterizada como primeira base do processo de industrialização. Esta atividade produtiva "teve início e posterior expansão com o desenvolvimento da agropecuária centrado na organização de unidades familiares de exploração" (TESTA, 1996 p. 189). Sua evolução caracteriza-se de um lado com as pequenas propriedades familiares agrícolas e de outro com os mercados consumidores interno e externo. 
ção da "integração formal dos produtores familiares de suíno e se pautou pela exigência de mudanças nas formas de produção e comercialização dos suínos" (TESTA et al, 1996 p. 189-190). A pequena propriedade familiar com a integração foi transformada em um simples ramo do processo produtivo da agroindústria, como produtora de matéria-prima sob o comando do capital agroindustrial. Esse sistema demonstra a ampliação constantemente da produtividade, selecionando espaços e produtores, na lógica da inclusão/exclusão de acordo com as necessidades do capital. A agroindústria intensifica a produção na cidade e amplia a produtividade no campo, sendo a matéria-prima apropriada nos moldes da produção capitalista nas pequenas propriedades, transformando a renda da terra num vantajoso negócio para agroindústria.

Essa (re) produção envolve a internalização de valores que são fomentados nas sociedades de classes construídas pelo modelo de produzir a vida pela sociedade dominante. Sendo assim práticas formativas no âmbito escolar desenvolvidas nas sociedades capitalistas são importantes, para (de) formar mão de obra que atenda as necessidades do agronegócio.

Para a classe dirigente, a educação dos trabalhadores assalariados

[...] deve estar orientada aos conteúdos mais simples, ou seja, em doses homeopáticas, pois o capital busca diuturnamente educar a classe trabalhadora para o consenso, interiorizando objetivos de garantir o processo de reprodução e acumulação de riquezas, mantendo as atuais formas de exploração e extração da mais-valia da classe que vive do trabalho. Interessa a classe dirigente formar para o consenso, com vistas a humanizar as formas de domínio e exploração (SKRZYPCZAK, 2013, p 103).

Pois, por meio dos comitês de Jovens, de Damas e dos projetos do CooperJovem, estímulo ao ensino EJA essas organizações objetivam estimular a cultura da cooperação/ consumo tanto no ambiente familiar como escolar. A qualificação/desqualificação dos trabalhadores atende aos interesses do capital agroindustrial, pois são escolarizados na lógica do mercado e do consumo capitalistas, como assalariado/integrado/associado do campo e da cidade.

Dessa forma há que se entender a gênese de formação das agroindústrias da região, representando uma das maiores concentrações da América Latina, incluindo a Diplomata S/A Industrial e Comercial e Cooperativas Agroindustriais Lar; empresas essas com complexa divisão técnica do trabalho e da produção que constantemente buscam novas formas de qualificar/proletarizar integrados/ associados do campo e trabalhadores da cidade para melhor atender suas demandas.

Como se tratam de dois trabalhos sintonizados na correlação será apresentado o modelo do Cooperativismo do Oeste do Paraná em especial da Cooperativa Agroindustrial Lar e em seguida da agroindústria Diplomata de Santa Catarina. O novo sistema de desenvolvimento no campo imprime o chamado "cooperativismo empresarial" que serve de ponte entre a indústria e a agricultura, tornando esta consumidora de insumos e de equipamentos, e a indústria processadora, que introduz novos modos de produção no campo e, nesse caso, a agricultura se torna fornecedora de matéria-prima para ser processada, para novamente ser consumida pela população rural, mantendo a relação: consumidor - vendedor - consumidor de produtos industrializados. A agroindústria se consolidou a jusante e a montante da agricultura, subordinando e explorando grande parte dos camponeses e propriedades rurais, assim mudando social, cultural e economicamente a estrutura rural. Como resultado das transformações do campo, a cooperativa estudada busca agregar valor ao produto. Sendo assim, diversifica a propriedade dos associados com linhas de produtos voltados ao agronegócio, intensificando as atividades para o desenvolvimento do setor agroindustrial. A Figura 3 a seguir mostra algumas atividades industriais que a Cooperativa Agroindustrial Lar desenvolve para agregar valor aos produtos.

Geografia Ensino \& Pesquisa, v. 18, n. 3 p. $37-54$, set./dez. 2014

Ben, M.; Skrzypczak, V; Schlosser, M.T.S.; Wizniewsky, C.R.F.

ISSN 2236-4994 


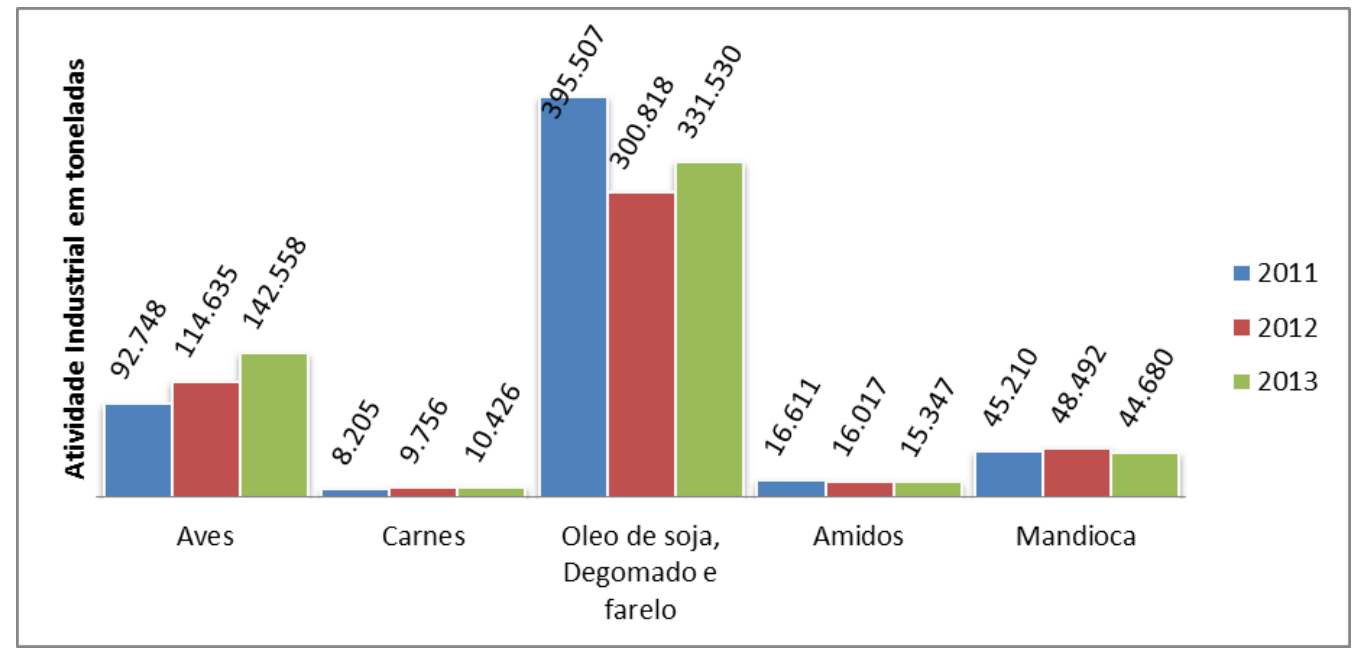

Fonte: Elaborado por Marilucia Ben, fevereiro de 2014

A Figura 3 identifica as atividades do agronegócio desenvolvidas nas propriedades dos associados camponeses que, por sua vez, são beneficiadas pela cooperativa. Demonstra o quanto as famílias trabalham nestas atividades para produzir tamanho resultado, neste sentido, os camponeses "arrendam sua propriedade", assumem todos os riscos da produção, compram os insumos e ainda desenvolvem relações não capitalistas de trabalho, recebendo pequena porcentagem do que produziu.

O planejamento estratégico atual da cooperativa Lar segue a lógica de profissionalização do quadro gerencial e dos associados. Ao mesmo tempo em que a cooperativa emprega funcionários há também os associados, portanto as capacitações se diferenciam. De acordo com o Relatório e Balanço (2013) a qualificação dos funcionários e do quadro gerencial se dá em parceria com o Sescoop/Pr, Fundação Dom Cabral, Fundação Getúlio Vargas, fornecedores dos produtos agroindustriais e auxílio para estudantes de graduação e especialização. As capacitações seguem os programas de Treinamento Técnico; Especialização em Engenharia e Segurança do Trabalho; Programa de Desenvolvimento de Gestores; Curso Técnico em eletromecânica; e Treinamentos Comportamentais. Ainda de acordo com o Relatório e Balaço (2013) para as famílias associadas são direcionados temas voltados a vida em família, melhorias de qualidade de vida, sua relação com a cooperativa e importância de sua participação no dia a dia. Os objetivos foram "oferecer alternativas de aumento da rentabilidade a seus associados através da diversificação de atividades e aprimoramento da gestão da propriedade" Relatório e Balanço (2013 p. 08)

Para desenvolver o quadro social foi criado o Comitê Central (como mostra a Figura 4), que é representado por lideranças das atividades de aves, suínos, leite, agricultura, amido, vegetais, ovos, jovens e mães, que procura desenvolver funções educativas e consultivas, especificamente participando de reuniões, cursos, viagens técnicas, tem assento à mesa do Conselho de Administração em todas as reuniões ordinárias e auxiliares do conselho de administração, levantando as sugestões, pretensões e reivindicações dos associados. As sugestões/reivindica-

Geografia Ensino \& Pesquisa, v. 18 n.3, p. 37-54, set./dez. 2014.

O trabalhador do campo e da cidade na lógica do capital agroindustrial: Santa Catarina e Paraná ções são consideradas desde que sejam voltadas para alinha que a cooperativa segue a lei do agronegócio, da competividade, da acumulação de capital.

Segundo a Organização das Cooperativas Brasileiras, a finalidade do Comitê Educativo/Central é a de realizar estudos e apresentar soluções sobre situações específicas. Pode adotar modificar ou fazer cumprir questões, inclusive no caso da coordenação de programas de educação cooperativista junto aos cooperados/camponeses, aos seus familiares e aos membros da comunidade da área de ação da cooperativa. Neste caso a educa- 
ção cooperativista objetiva motivar adolescentes ao cooperativismo empresarial que prima pela competividade e pelo agronegócio que implica no consumo de pacotes tecnológicos. Na concepção de Mészáros (2008), muito diferente da qualificação de mão de obra para o sistema capitalista, a educação deve ser o sustentáculo da vida de cada pessoa e que as soluções para a educação necessitam ser essenciais, pois funcionam predominantemente como sistema de internalização de valores, conhecimento e cultura, ordenando concepções de mundo. Nesse sentido, é fundamental que a educação, em vez de qualificar mão de obra, seja capaz de romper com a própria lógica do sistema capitalista.

Figura 4-Organização do Quadro Social da Cooperativa Agroindustrial Lar

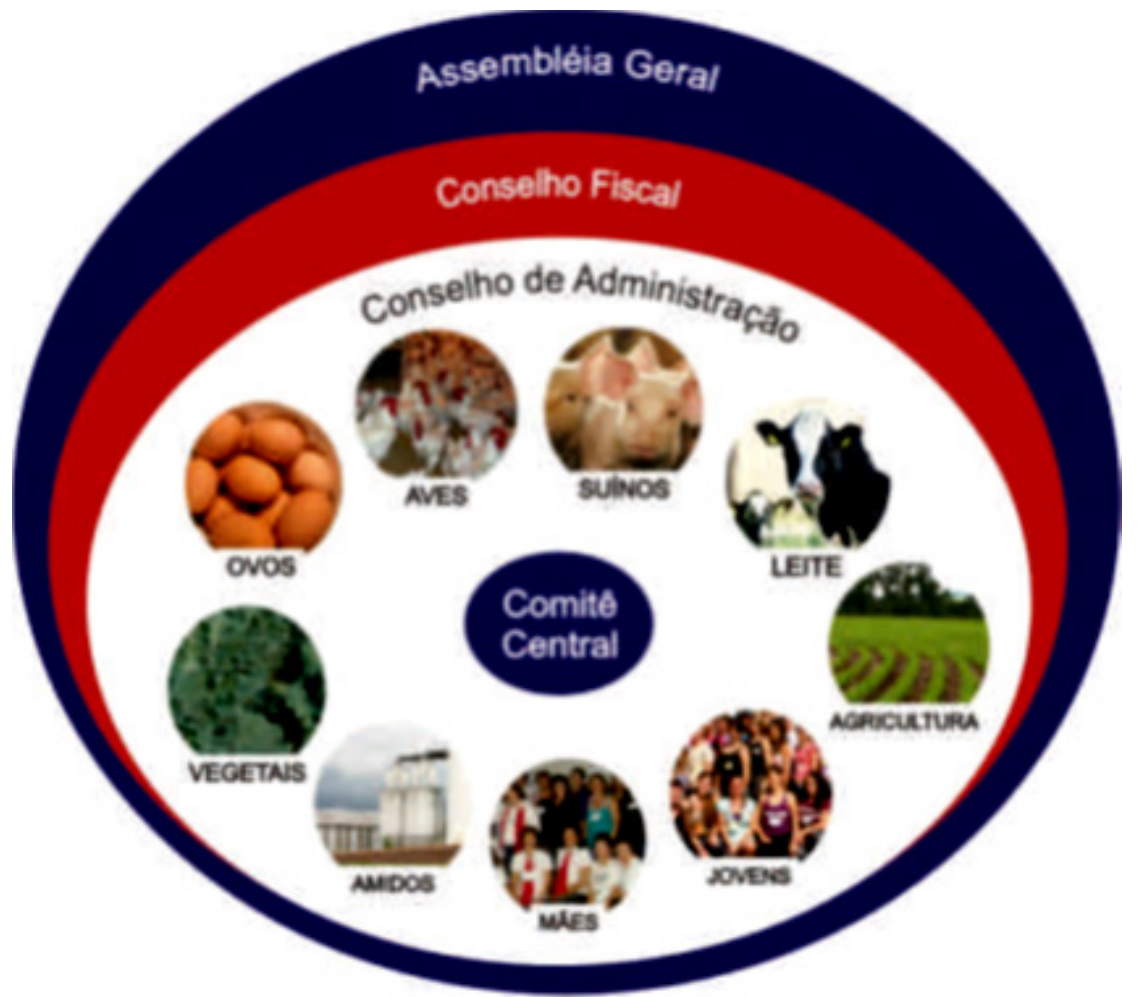

Fonte: Relatório e Balanço 2010 da Cooperativa Agroindustrial Lar.

As cooperativas que atuam no Oeste paranaense (como Lar, Coopavel, Copagril, entre outras) dispõem de programas de cursos para capacitar a formação de seus associados, formando mão de obra para o desenvolvimento de atividades como gado leiteiro, avicultura, suinocultura, apicultura, entre outras. Os cursos proporcionados por elas aos seus associados, mães e jovens são planejados e executados pelo Comitê Educativo, formado por representantes da comunidade, que utiliza fichas, formulário e planilha com o objetivo de manter a Diretoria Executiva informada das necessidades dos cooperados/camponeses. O Comitê Educativo possui metas relacionadas à quantidade de reuniões e limite mínimo de sugestões trazidas pelos cooperados/camponeses.

A educação no cooperativismo é regularizada no Brasil baseada no rochdaleanismo pela Lei Federal n ${ }^{\circ} 5.764 / 1971$, artigo $4^{\circ}$, que define a cooperativa como sociedade de pessoas de natureza civil de forma e natureza jurídica própria, sem finalidade lucrativa. Entre as características merecem destaque a indivisibilidade dos Fundos de Reserva e de Assistência Técnica, Educacional e Social, que, por sua vez, são inspirados precursores do pensamento cooperativo. Dentre os socialistas utópicos que influenciaram o cooperativismo nascente, merece destaque Robert Owen, considerado também como grande reformador

Geografia Ensino \& Pesquisa, v. 18, n. 3 p. $37-54$, set./dez. 2014

Ben, M.; Skrzypczak, V; Schlosser, M.T.S.; Wizniewsky, C.R.F. 
social e educacional utópico, que introduziu várias inovações em favor dos operários, exaltando a educação e sua eficácia. A educação era utilizada para intervir entre os trabalhadores e substituir o alcoolismo pela sobriedade e as arruaças pela ordem. Em seu pensamento, considerava que o homem é resultado de seu meio social (PINHO, 1982). Nesse sentido, as famílias dos cooperados/camponeses são tidas como unidades básicas de produção, por isso são envolvidas ao máximo nas atividades da cooperativa e os cursos desenvolvidos no Centro de Treinamento da Lar, proporcionados pelo Comitê Educativo, se encaixam na educação não formal: "Desenvolvimento Pessoal"; "A Arte da Liderança"; "Postura Social e Profissional", "Desenvolvendo Competitividade", "Encontro de Jovens Cooperativistas do Paraná" (com palestras direcionadas ao cooperativismo, sendo: "Como transformar ideias em resultados"; "Cooperativismo, a força empreendedora"; "A importância da ação política para o desenvolvimento cooperativista"). Tais atividades educativas direcionam a aprendizagem para ser seguida de eixos temáticos voltados para a linha do cooperativismo agroindustrial e incorporados pelos associados. Mas a atuação da cooperativa/agroindústria não para por aí, a educação formal também é contemplada, com atividades no Ensino Fundamental I, graduação e especialização que estão se desenvolvendo de forma crescente no Oeste do Paraná. Cursos são ofertados aos professores do Ensino Fundamental I para desenvolver o cooperativismo em sala de aula. Já a graduação e a especialização a cooperativa ajuda financeiramente para que os funcionários que desejam aprofundar seus estudos sobre o cooperativismo, porém levando em consideração os interesses do capital agroindustrial.

São desenvolvidas intensas atividades pelo Comitê Educativo da cooperativa, direcionadas ao Coopermães e ao Cooperjovens. Estes cursos buscam organizar e capacitar às mães e os jovens cooperativistas. O Cooperjovem, composto pelos filhos e pelas filhas de associados, é coordenado, orientado e treinado pela cooperativa. Esta cooperativa dispõe de um centro de treinamento onde são desenvolvidos diversos cursos que atendem a comunidade cooperada.

Esse modelo de cooperativismo vem (des)qualificando os seus associados para atender às exigências do capital agroindustrial, o que, segundo a filosofia cooperativista adotada, é, em realidade, uma desqualificação, pois, com a introdução de novas tecnologias no processo produtivo, o trabalho do cooperado simplifica-se. Mesmo assim, porém, aos associados "[...] cada vez mais é exigida educação e cultura para manter a competitividade, numerado que se globaliza progressivamente [...]" (TESTA et al., 1996 p. 77), com a introdução de novas tecnologias de mecanização e automatização de aviários e de chiqueirões. As novas tecnologias, como aviários automatizados, com bebedouros e comedouros automáticos, alarmes de alerta, rações melhoradas, nesse caso, são introduzidas nas propriedades rurais dos associados através de cursos desenvolvidos pelos programas do Comitê Educativo.

A categoria para relacionar educação e cooperação é o trabalho, referenciado na teoria marxista de produção como base da humanização e da aprendizagem. O trabalho cooperativo e a educação servem de aliados, partindo do entendimento de que o ser humano aprende produzindo. Neste sentido os cooperados ao participar de programas educativos da cooperativa acaba consumindo os pacotes tecnológicos do agronegócio se sujeitando a ficar submisso ao uso de tecnologias a montante e a jusante do sistema produtivo. A educação "[...] se apresenta como uma ação entre sujeitos, isto é, como uma ação social" (BOUFLEUER, 1997, p. 22).

Neste sentido, o sistema educacional tem assumido caráter estratégico para os secapital. Esse sistema segue a lógica da mercantilização da vida para o "sentido de ter", que é materializado na apropriação privada da riqueza produzida socialmente e desenvolvida 
pelo modelo estético que Mészáros (1981, p. 263) chama de “[...] alienação de todos os sentidos, subordinados ao 'sentido de ter"'. A alienação, segundo o autor, segue a lógica da educação estética na tentativa isolada de enfrentar a desumanização dos processos educacionais na sociedade capitalista, caracterizado pela (re)produção dos indivíduos incorporados no processo de produção dominante.

Essa (re)produção envolve a internalização de valores que são fomentados nas sociedades de classes construídas pelo modelo de produzir a vida pela sociedade dominante. Sendo assim, práticas formativas no âmbito educacional desenvolvidas nas sociedades capitalistas são importantes para (de)formar mão de obra e atender às necessidades do agronegócio e do consumo.

Em ambas pesquisas, da Cooperativa Agroindustrial Lar (Paraná) e Diplomata S/A Industrial e Comercial (Santa Catarina), foi constatado que os associados/ integrados/ trabalhadores são escolarizados a seguir as exigências determinadas pelo capital agroindustrial, impondo novos ritmos à produção e obtenção da matéria-prima, transformando-o em simples produtor de matéria-prima (aves e suínos) para a agroindústria. Esta busca constante reforça novas formas de qualificar/desqualificar o trabalhador, instalando " [...] verdadeiro processo pedagógico que tem por objetivo a educação técnica e política do trabalhador, determinada pelos interesses do capital [...]" (KUENZER, 2011, p. 12), exercendo certa concepção de mundo.

A Diplomata S/A Industrial e Comercial desqualifica os associados/ integrados/ trabalhadores, pois o capital controla o processo produtivo, “[...] expropriando o saber do operário, [expropriação realizada] através da divisão e parcelarização do trabalho" (CRUZ, 2000 , p. 29). Na medida em que a ciência é incorporada pela indústria no processo produtivo, intensifica a subordinação do trabalhador e a expropriação do seu saber sobre o produto do seu trabalho, a mercadoria (BRAVERMAN apud CRUZ, 2000, p. 29). Esse domínio do capital sobre o trabalho está determinado pelas relações capitalistas de produção, sendo que "[...] a desqualificação do trabalhador, operada pelo trabalho heterogerido, que acresce à alienação do produto do trabalho a alienação do conteúdo e das decisões sobre o trabalho pelo trabalhador" (KUENZER, 2011, p. 13).

Com a divisão do trabalho e da propriedade privada no sistema capitalista, o trabalhador produz objetos/mercadorias que se tornam estranhos ao seu próprio trabalho, pois são exteriores e, portanto, não lhe pertencem, visto que são apropriados pelo capital na condição destrutiva do trabalho estranhado e da desrealização do trabalhador assalariado (ANTUNES, 2004).

Boa parte das atividades da economia regional está voltada para atender à demanda das cooperativas agroindustriais e também das agroindústrias, que constantemente introduzem novas técnicas, tenrificando o campo e a cidade, com a instalação de máquinas e equipamentos auto informatizados, tanto para a obtenção da matéria-prima, como para a produção, a circulação e o consumo, tudo voltado, sobretudo, para atender ao mercado internacional, transformando assim consideravelmente seus espaços "do fazer", agora carregados de ciência, técnica e informação (SANTOS, 2008).

Os espaços do campo são atualmente forçados a usar as características e possibilidades econômicas próprias em benefício do todo mundializado, para atender as necessidades imediatas de acumulação do capital. A indústria impõe as necessidades crescentes da produção e o campo se adapta técnica e socialmente para atendê-las. As determinações são impostas pelo capitalismo central que demanda de maior produtividade agrícola. Assim as indústrias e cooperativas atendem os interesses do capital internacional, reestruturando a cadeia produtiva e o ritmo de crescimento, visando ampliar os lucros. Estas mudanças extrapolam o interior das agroindústrias e chegam ao campo, reestruturando as pequenas propriedades camponesas familiares para atender as necessidades do capital, pois

Geografia Ensino \& Pesquisa, v. 18, n. 3 p. $37-54$, set./dez. 2014

Ben, M.; Skrzypczak, V; Schlosser, M.T.S.; Wizniewsky, C.R.F.

ISSN 2236-4994 
[...] O cuidado na obtenção de matéria-prima, com qualidade, em menor espaço de tempo e com maior rendimento, dá-se com um intenso processo de modificação de toda cadeia produtiva. Isto quer dizer que todo o processo de produção da matéria-prima, ao longo deste tempo, tem passado por intensas transformações [...] (ALBA, 2002 p. 112-113).

São trabalhadores que apanham os frangos no interior do aviário após a engorda para o transporte até a agroindústria. São contratados por empresa terceirizada, porém do camponês integrado são descontados valores do lote para o pagamento da empresa. $\mathrm{Na}$ prática a agroindústria terceiriza o serviço e quem paga é o camponês.

Geografia Ensino \& Pesquisa, v. 18, n.3, p. $37-54$, set./dez. 2014

O trabalhador do campo e da cidade na lógica do capital agroindustrial: Santa Catarina e Paraná
As mudanças vão desde a automatização dos aviários, passando pelo processo produtivo, levando em consideração os interesses da agroindústria que amplia o número de aves e reduz o tempo de engorda para o abate. Assim a agroindústria condiciona o camponês familiar às formas do trabalho alienado/estranhado, pois o processo produtivo no sistema de integração é dominado pela empresa e desconhecido pelo camponês.

A agroindústria expropria o saber do camponês sobre o trabalho, que antes da integração era realizado sem a interferência do capital. $\mathrm{Na}$ propriedade o quintal deu lugar ao aviário e a criação das galinhas "caipiras" livres ou soltas cede lugar à criação de aves confinadas e geneticamente modificadas. O camponês não comanda mais a produção, que está sob o comando da agroindústria, que determina o que, quando e como produzir, a partir das necessidades do capital, criando novas relações de trabalho e de produção fora do aviário, “[...] com a família, com outros avicultores, com o grande capital e seus representantes, com os técnicos e veterinários que prestam a assistência técnica, com os apanhadores ${ }^{2}$ de frango" (MIZUSAKI, 2009, p. 208). São relações capitalistas entre a agroindústria e o camponês integrado, aonde o tempo e o ritmo de trabalho não se dão pela natureza, mas conduzidos pelo capital, pois “[...] não é o tempo da primeira natureza quem dita o ritmo de trabalho, mas o do frango reproduzido conforme o ritmo imposto pela biotecnologia" (MIZUSAKI, 2009, p. 208).

O ritmo de crescimento das aves ocorre a partir do tempo do capital, segundo as necessidades da agroindústria. Muda-se a genética, determina-se a cor das penas, programa-se o crescimento e o peso das aves com o uso da ciência e da tecnologia. O bem estar das aves é aparente, mas determinado pelo capital, que confina as aves em galpões, artificializa a alimentação e introduz a química por meio dos medicamentos e vacinas na pequena propriedade camponesa. As liberdades da produção camponesa que antes eram determinadas pelo ritmo da natureza, na atualidade estão a serviço do capital, sob o comando da agroindústria, que domina o processo produtivo. O bem estar animal está a serviço do bem estar do capital, que busca reduzir o tempo de produção da matéria-prima (frango) para o abate, industrialização e comercialização.

Para a agroindústria a dedicação dos camponeses no sistema de integração deve ser integral, pois o resultado depende do esforço e da administração na atividade. Assim as aves precisam estar bem alimentadas, o espaço no interior do aviário precisa estar limpo e desinfetado, a fim de evitar doenças no lote. Qualquer anormalidade no lote precisa ser imediatamente comunicada ao técnico da agroindústria. Nada deve interferir no comportamento das aves, pois precisam crescer de forma acelerada, segundo as necessidades determinadas pela indústria. Para o capital, a "liberdade" do camponês é vigiar diuturnamente o lote, pois a "[...] aceitação e boa vontade do avicultor são suficientes para um bom resultado" (N.P.F., Entrevista, 21 out. 2012). A vontade do camponês subjetivamente é o interesse da agroindústria em ampliar os lucros, sendo uma tarefa possível pela educação/ formação do camponês pelo capital.

Entendendo-se o espaço como resultado do desenvolvimento das forças sociais, políticas e econômicas, as preocupações percorrem a abordagem geográfica que dê conta de articular essa estrutura com o espaço por ela (re) produzido, sendo que as constantes e rápidas transformações impostas pela agroindústria no campo e na cidade também ocorrem para os associados, que agora necessitam de maior escolarização/proletarização, visando atender à reestruturação produtiva sob o comando da agroindústria. Para Raffestin (1993, p.143), ao "[...] se apropriar de um espaço, concreta ou abstratamente [...], o ator 'territorializa' o espaço". 
Quadro 1-Liberdades e bem estar capital.

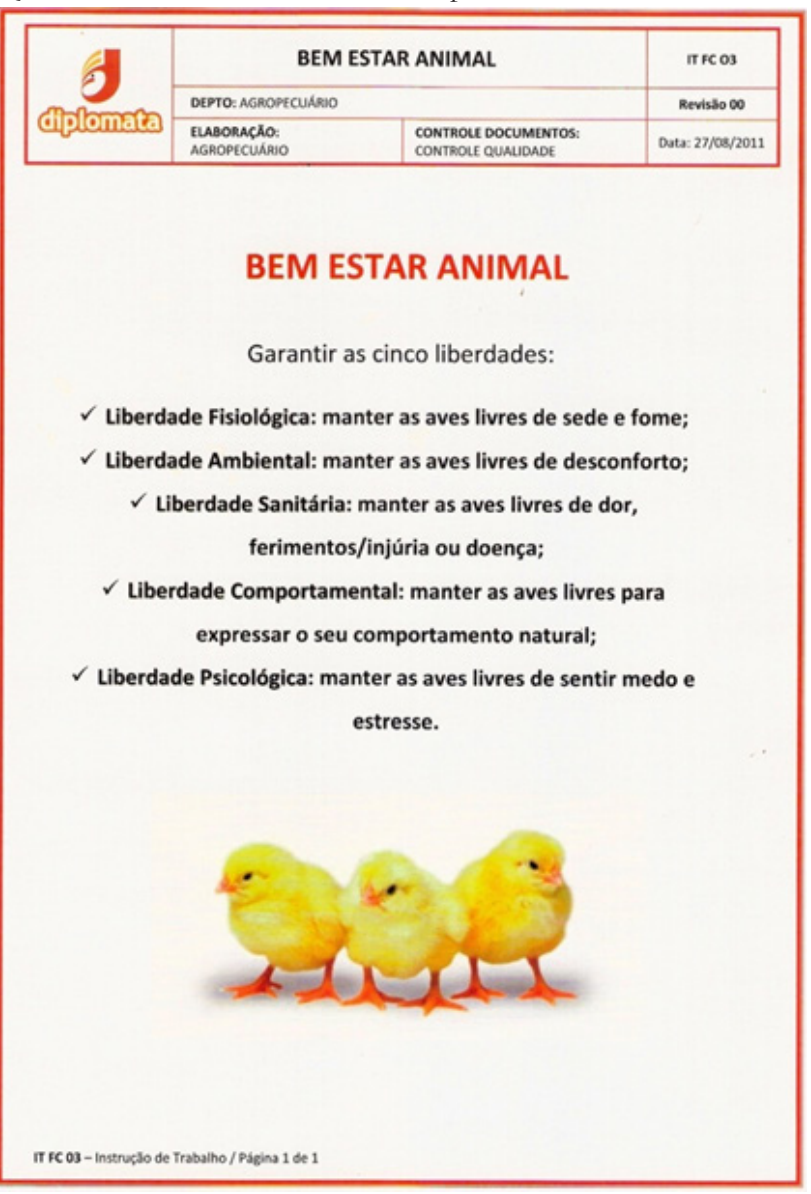

Fonte: Família Pavan. Adaptado por Valdir Skrzypczak.

O quadro foi elaborado pelo departamento de agropecuária da agroindústria Diplomata como instrução de trabalho no sistema de integração. A agroindústria determina a relação de trabalho do camponês familiar com a produção avicola, segundo as necessidades impostas pelo capital. O folder de instrução de trabalho foi distribuido para os camponeses integrados e trabalhado pelos técnicos da indústria, como material de educação/formação no campo, no ano de 2011, devendo estar visivel no interior do galpão.

Assim, a formação socioespacial dos municípios de Missal e de Medianeira no Paraná, a partir da instalação da cooperativa agroindustrial Lar e de Xaxim, no Oeste de Santa Catarina coma agroindústria Diplomata, desenvolveu e exigiu novas funções do espaço urbano e rural, ao mesmo tempo em que vem exigindo maior escolarização / proletarização de seus associados, tanto do campo, como da cidade. Para Arroyo (2009, p. 80), as propostas e os conteúdos das escolas seriadas são iguais e têm "[...] a mesma finalidade: habilitar todas as crianças e jovens do campo e da cidade para as experiências modernas de produção e do trabalho".

Os associados/camponeses familiares estão sendo (des)escolarizados/(des)qualificados para o mercado, ou seja, para a proletarização da própria agroindústria. De acordo com Cruz,

[...] as novas exigências requeridas pelo sistema flexível de produção trouxeram profundas mudanças a todos os trabalhadores. [...] enquanto alguns tornam-se superespecializados, outros requalificam-se e outros ainda sofrem uma desqualificação. Por outro lado, verifica-se que tanto os trabalhadores qualificados quanto os desqualificados estão sendo marginalizados do sistema produtivo; o desemprego, a subcontratação, a informalidade são inerentes a este modelo de produção (CRUZ, 2000, p. 33).

Geografia Ensino \& Pesquisa, v. 18, n. 3 p. $37-54$, set./dez. 2014

Ben, M.; Skrzypczak, V; Schlosser, M.T.S.; Wizniewsky, C.R.F.

ISSN 2236-4994 
As novas exigências impostas aos associados/cooperados/integrados/trabalhadores e a educação a eles oferecida levam as escolas a se adaptarem para atender aos interesses do capital, sobretudo ao capital da agroindústria da região. Há a necessidade de “[...] entender os processos educativos na diversidade de dimensões que os constituem como processos sociais, políticos e culturais; formadores do ser humano e da própria sociedade" (ARROYO; CALDART; MOLINA, 2009, p. 12-13).

$\mathrm{Na}$ relação campo/cidade existe a necessidade de pensar a escolarização das familias residentes no campo, pois que, na atualidade, crianças e adolescentes são levados a estudar nas escolas urbanas, recebendo os conteúdos direcionados às práticas urbanas e ao mercado. Assim são instruídas na dinâmica do capital industrial, no aumento da produtividade e na inserção da ciranda da integração/ proletarização com os grupos agroindustriais do Oeste catarinense e paranaense.

Entender os espaços da cidade e do campo, contextualizados com a realidade econômica e educacional dos associados/cooperados/integrados/trabalhadores e a inserção na dinâmica do capital, é tarefa imprescindível. Para Mészaros (2008), a educação institucionalizada nos últimos 150 anos serviu “[...] ao propósito de não só fornecer os conhecimentos e o pessoal necessário à máquina produtiva em expansão do sistema do capital [...]", mas para transmitir e legitimar os valores e os interesses do capital (MÉSZAROS, 2008, p. 35).

A (des)qualificação dos associados/cooperados/integrados/trabalhadores/camponeses familiares atendem aos interesses do capital agroindustrial, pois são escolarizados na lógica do mercado e da produção, como se assalariados do campo e da cidade fossem.

Dessa forma, há que se entender a gênese de formação das agroindústrias da região, representando uma das maiores concentrações desse tipo de cooperativas/empresas da América Latina. Nelas se incluem tipicamente cooperativas agroindustriais, a exemplo da Lar e indústrias como a Diplomata, que possuem complexa divisão técnica do trabalho e da produção e que constantemente buscam novas formas de qualificar/proletarizar integrados/associados/camponeses familiares e trabalhadores da cidade para melhor atender às suas demandas.

A dinâmica de formação dos novos espaços rural/urbano imposta pela agroindustrialização é dialética e desenvolvida na lógica do sistema capitalista. Espaços e pessoas são incorporados ou excluídos na medida em que se fazem necessários ou não ao capital, como é o caso da formação socioespacial de Missal e de Medianeira, também de sua população, ou seja, dos associados/cooperados/integrados/ trabalhadores/camponeses familiares do campo e da cidade que, direta ou indiretamente, estão subordinados à lógica de acumulação capitalista das cooperativas agroindustriais. Há urgência em instituir escolas diferentes e que desenvolvam no educando a formação para a vida, objetivando produzir conhecimento, criar habilidades e formar sua consciência (CALDART, 2009). Trata-se de escolas que vinculem a educação com as questões sociais inerentes à própria realidade do campo e da cidade, escolas contrárias às atuais, que estão comprometidas em reproduzir as tradicionais relações sociais de produção entre o capital e o trabalho e em atender aos interesses de acumulação capitalistas (FERNANDES, 1999, p. 53).

O perfil da dinâmica agroindustrial das regiões Oeste paranaense e catarinense está baseado na relação da chamada integração agroindustrial com pequenos, médios e grandes produtores rurais. Esse sistema busca a ampliação constantemente e aumento da produtividade, selecionando espaços e capacitando produtores, na lógica da inclusão/exclusão de acordo com as necessidades do capital. Destacam-se neste processo culturas que auferem maior rentabilidade ao setor agroindustrial, onde constituem objeto de interesse e fusão destas empresas com a produção de diferentes produtos agrícolas. Assim

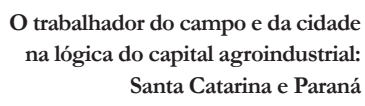


Na lógica da (des)qualificação/(des)educação dos associados o cooperativismo procura disseminar seus princípios com a "educação" cooperativista que objetiva, de acordo com Nascimento (1982), formar membros conscientes, técnicos competentes e cooperativas organizadas voltadas ao agronegócio.

Os aspectos ligados à "educação" cooperativista são diversificados. No período de 1844 em diante, o cooperativismo dos Tecelões de Rochdale era utilizado para formar seus membros com vários tipos de ensinamento, incluindo alfabetização, que, naquela época, se voltava somente para as elites. Segundo Nascimento (1982), a educação cooperativista tem finalidade de reformar a sociedade para seguir o cooperativismo. Suas formas recaem sobre a educação cooperativista formal e educação cooperativista informal. A primeira compreende as cooperativas escolares, com cursos do sistema formal de ensino voltado para o cooperativismo, instituições privadas e públicas. A segunda está voltada para a atuação prática das instituições cooperativas privadas e públicas, e das cooperativas em geral.

$\mathrm{Na}$ chamada "educação cooperativa informal", Nascimento (1982), destaca a animação cooperativista e a animação informal ministrada por cooperativas e por órgãos cooperativistas. A animação cooperativista atua na autoconsciência, auto-organização, autogestão, autodesenvolvimento. Essa educação objetiva despertar no indivíduo as próprias potencialidades na comunidade e despertar os indivíduos para a organização das células sociais de acordo com as exigências e transformações da época.

Já a animação informal ministrada por cooperativas e por órgãos cooperativistas proporciona o treinamento técnico-administrativo em diversos campos com ênfase na extensão agrícola, objetivando habitação e assistência ao trabalhador rural em suas atividades de produção, orientação, preparação e treinamento técnico de jovens, filhos dos associados. Também enfatiza o ensino da economia doméstica para as mães nas famílias associadas, intervindo com ensinamentos relativos ao aproveitamento econômico dos produtos alimentícios ali produzidos, ensinamentos visando também à fixação do homem no campo e a manutenção dos seus hábitos (NASCIMENTO, 1982).

A educação não formal tem influenciado de modo significativo às novas formas de produção no campo, sendo que na região Oeste do Paraná são objeto de atuação das empresas e das cooperativas agroindustriais. Segundo Gadotti (1998), "Os campos de ação da educação popular comunitária podem ser tanto a escola formal, como a não-formal, as organizações econômicas e populares, as escolas produtivas e mesmo as microempresas" (GADOTTI, 1998, p. 307).

Para Gohn (1999), “[...] a educação não-formal designa um processo com quatro campos ou dimensões, que correspondem a suas áreas de abrangência" (GOHN, 1999, p. 98), analisa na dimensão da educação do cooperativismo agroindustrial. Essas dimensões que abrangem a educação não formal são: 1) aprendizagem política dos direitos dos indivíduos enquanto cidadãos; 2) capacitação dos indivíduos para o trabalho, por meio da aprendizagem de habilidades e/ou potencialidades; 3 ) aprendizagem e exercício de práticas que capacitam os indivíduos a se organizarem com objetivos comunitários, voltadas para a solução de problemas coletivos cotidianos; 4) aprendizagem de conteúdos que possibilitem leituras de mundo que abrangem o que se passa ao seu redor; 5) educação desenvolvida na mídia e pela mídia. Tais dimensões são consideradas processos de autoaprendizagem e aprendizagem coletiva por meio de experiências em ações organizadas a partir de eixos temáticos seguindo a lógica do que se pretende socializar para um fim.

Empresas como a Brasil Foods, Aurora, Diplomata S/A Industrial e Comercial buscam a partir do CEJAX (Centro de Educação de Jovens e Adultos de Xaxim) e CEJA (Centro de Educação de Jovens e Adultos), ampliar a escolarização/proletarização dos trabalhadores da agroindústria, do campo e da cidade, visando atender às constantes exigências impostas pelo capital, "[...]com uma força de trabalho qualificada, flexível a tais mudanças, capaz de potencializar o uso da tecnologia e aumentar a produtividade [...]'(CRUZ, 2000 p. 33), na lógica do discurso empresarial/escolar do desenvolvimento de trabalhadores com novas habilidades e competências.

Geografia Ensino \& Pesquisa, v. 18, n. 3 p. $37-54$, set./dez. 2014

Ben, M.; Skrzypczak, V; Schlosser, M.T.S.; Wizniewsky, C.R.F.

ISSN 2236-4994 
A dinâmica de formação desses espaços rural/urbano, impostos pela agroindustrialização são dialéticos e desenvolvidos na lógica do sistema capitalista. Espaços e pessoas são incorporados ou excluídos na medida em que se fazem necessários ou não ao capital, como é o caso da formação socioespacial de Xaxim, também de sua gente, ou seja, dos trabalhadores do campo e da cidade que direta ou indiretamente estão subordinados à lógica de acumulação capitalista das agroindústrias. Necessita, portanto, de uma nova escola que desenvolva no educando a formação para a vida, "produz conhecimento, cria habilidades e forma sua consciência". (CALDART, 2009, p. 101). Uma escola que "[...] vincule a educação às questões sociais inerentes à sua realidade [...]," (idem, 2009 p. 101) do campo e da cidade e não a escola que reproduz as atuais relações sociais de produção entre o capital e o trabalho e atende aos interesses de acumulação capitalistas (FERNANDES, 1999, p. 53); e não a escola formal que reproduz e intensifica as atuais relações sociais de produção e reprodução do capital e atende os interesses da acumulação capitalista. Nesta lógica perversa, o capital transforma o trabalhador em simples produtor de mercadorias; o trabalho educativo passa a ser trabalho estranhado/ fetichizado, orientando a produção do campo e da cidade as necessidades de manutenção das condições de exploração e extração da mais-valia da agroindústria sobre o conjunto dos proletários.

A classe trabalhadora se movimenta, cria e recria novas maneiras de resistir contra a opressão do capital. Nesse movimento de práxis dos trabalhadores, a temática não se encerra neste trabalho, mas é meio para a realização de novos estudos.

\section{Considerações finais}

A estrutura desenvolvida nas regiões Oeste de Santa Catarina e Oeste do Paraná são caracterizadas pela forte presença de agroindústrias e pelo cooperativismo agroindustrial, formando relações dialéticas com as pequenas propriedades familiares produtoras de matérias-primas.

A estruturação e a modelação do espaço, tanto rural como urbano, desenvolvidos, sobretudo pelos complexos agroindustriais aproximam as relação entre o campo e a cidade, a qualificação/desqualificação dos associados/cooperados/integrados/trabalhadores/camponeses e a reestruturação das atividades produtivas principalmente rurais, impostas pelas atividades urbanas, sobretudo pelas agroindústrias.

As constantes e rápidas transformações ocorridas no campo a partir da década de 1970, com o processo de modernização, desenvolveram intensas transformações nas relações estabelecidas entre os pequenos produtores familiares e as agroindústrias, beneficiando profundamente estas empresas. A crescente acumulação capitalista, com o aumento dos lucros, passou a formar gigantescas empresas nas regiões Oeste catarinense e Oeste paranaense, responsáveis por grande parte da economia regional e pelo domínio das pequenas propriedades rurais. As agroindústrias dominam as técnicas, a produção e a produtividade das matérias-primas, o que as possibilita determinar o valor médio da produção na agricultura integrada "dominando" também os associados/ cooperados/ integrados/ trabalhadores/ camponeses.

De acordo com Testa et al (1996), na década de "1980 existiam 67 mil suinocultores, para os quais a atividade tinha significativa parcela de renda" sendo que hoje é acessível para um pequeno grupo de produtores, "estimada em 20 mil suinocultores, com tendência de concentração ainda maior" (TESTA et al, 1996 p. 23). O modelo de desenvolvimento imposto nas regiões Oeste de Santa Catarina e Oeste do Paraná está centralizado em alguns poucos frigoríficos e cooperativas agroindustriais que

Geografia Ensino \& Pesquisa, v. 18 n.3, p. $37-54$, set./dez. 2014

O trabalhador do campo e da cidade na lógica do capital agroindustrial: Santa Catarina e Paraná poneses e suas respectivas famílias, no campo e na cidade.

As constantes modificações nas pequenas propriedades e a modernização das atividades avícolas e suinocultoras possibilitaram às agroindústrias selecionar os associados/ cooperados/integrados/trabalhadores/camponeses, excluindo propriedades e produtores, vindo a marginalizar famílias inteiras.

A lógica no uso do espaço rural sege padrões globais, interferindo na vida cotidiana 
dos associados/cooperados/integrados/trabalhadores/camponeses, modificando seus hábitos e suas tradições, introduzindo o consumo de produtos industrializados. Acabam (re) produzindo novos significados nos modos de produção, como animais em confinamento, o que requer reestruturações nas propriedades agrícolas - o galinheiro dá lugar ao aviário, as galinhas caipiras, patos, gansos, etc., são exterminados devido à criação das aves em confinamento. Há um emplacamento do espaço rural a entrada da propriedade, bem como as comunidades são marcada com placas para identificá-las, assim como o proprietário e a qual empresa pertence, facilitando a localização para o motorista do caminhão que transporta ração e aves, bem como para a visita dos técnicos. O uso das técnicas para a criação desses animais em confinamento também se modifica, e a tecnologia implantada em alguns casos supera até o valor da propriedade.

Nesse sentido ao mesmo tempo em que aos associados/ cooperados/ integrados/ trabalhadores/ camponeses é exigida maior qualificação/escolarização, suas atividades no campo e na cidade simplificam-se, pois estes espaços, carregados de ciência e tecnologia, intensificam a divisão do trabalho e o tornam (trabalho) mais simples, fragmentam o trabalho e o trabalhador do seu produto, a mercadoria, sob o comando da máquina e esta do capital. O sistema de ensino contribui significativamente para que isso ocorra, pois segundo Marx, K; Engels, F.; (2004) esse sistema é entendido como a concreta qualificação da força de trabalho para alcançar seu aproveitamento máximo com ajustes e integração dos indivíduos no sistema. A qualificação da força de trabalho é encaminhada para a forma de produção. Portanto a qualificação/desqualificação do trabalhador intensifica a extração da mais-valia pelo capital agroindustrial, pois o torna mais produtivo sob o comando da máquina e da produção.

As bases técnicas e econômicas da agropecuária foram gradativamente sendo substituídas, seja para o cultivo de plantas, seja para a criação de animais, pois as anteriores se mostravam incompatíveis com as novas formas de produção, de distribuição e de consumo. O novo modelo de produção agropecuário é baseado na incorporação da ciência, da tecnologia e da informação com o intuito de aumentar a produtividade, culminando em transformações econômicas e, portanto, em transformações socioespaciais e ambientais.

Este cenário de reproduções individualistas do capital, pergunta-se: São essas novas exigências que manterão o jovem no Campo? Este Jovem que segundo os projetos educacionais das cooperativas garantirá a permanência da mesma no futuro. De fato é ambíguo e contraditório, como a maioria das discussões que perpassam entre a teoria e a prática do cooperativismo.

\section{Referências}

ALBA, Rosa Salete (Org.). Estudos de geografia agrária do oeste catarinense. Chapecó: Argos, 2008. 173 p.

Espaço Urbano: os agentes da produção em Chapecó. Chapecó: Argos, 2002. 184p.

ANTUNES, Ricardo (org.). A Dialética do trabalho. São Paulo: Expressão Popular, 2004.

ARROYO, Miguel Gonzáles; FERNANDES, Bernardo Mançano. A educação básica e o movimento social do campo. Brasília: [s.n.], 1999.

ARROYO, Miguel Gonzáles; CALDART, Roseli Salete; MOLINA, Mônica Castagna (org.). Por uma educação do campo. $4^{\text {a }}$ ed. Petrópolis, RJ: Vozes, 2009.

BEN, Marilucia. Os "nós" da territorialização da Cooperativa Agroindustrial Lar no oeste paranaense. Dissertação de Mestrado, Unioeste, Campus de Francisco Beltrã̃o, 2011.

Geografia Ensino \& Pesquisa, v. 18, n.3 p. $37-54$, set./dez. 2014

Ben, M.; Skrzypczak, V; Schlosser, M.T.S.; Wizniewsky, C.R.F.

ISSN 2236-4994 
CRUZ, Dulcinéia da. A Formação do 'Total Trabalhador SADIA': Um estudo de caso sobre o processo de qualificação dos trabalhadores na Sadia S/A. 2000,150 f. Dissertação (Mestrado em Educação). Programa de Pós-Graduação do Centro de Educação. UFSC. Florianópolis.

GADOTTI, Moacir. Pensamento pedagógico brasileiro. 2. ed., São Paulo: Ática, 1988.

GOHN, Maria da Gloria. Educação não-formal e cultura política. São Paulo: Cortez, 1999.

GREGORY, Valdir. Os Eurobrasileiros e o Espaço Colonial: migrações no Oeste do Paraná (1940 -1970). Cascavel: edunioeste, 2002. 306p.

KUENZER, Acácia Zeneida. Pedagogia da Fábrica: As relações de produção e a educação do trabalhador. $8^{\mathrm{a}}$ ed. São Paulo: Cortez, 2011.

MARX, Karl; ENGELS, Friedrich. [tradução de Rubens Eduardo Frias]. Textos sobre educação e ensino. $4^{\mathrm{a}}$ ed. São Paulo: Centauro, 2004.

MARX, Karl. [tradução de Reginaldo Sant'Anna].O capital: crítica da economia política. Livro 1. $29^{a}$ ed. Rio de Janeiro: Civilização Brasileira, 2011. v. 1.

MÉSZÁROS, I. Marx: a teoria da alienação. Tradução: Waltensir Dutra. Rio de Janeiro: Zahar, 1981.

MÉSZAROS, István. [tradução Isa Tavares]. A educação para além do capital. $2^{a}$ ed. São Paulo: Boitempo, 2008.

MIZUSAKI, Márcia Yukari. Território e reestruturação produtiva na avicultura. Dourados, MS: Editora da UFGD, 2009.

PAULINO, Eliane Tomiasi. Por uma geografia dos camponeses. $2^{\mathrm{a}}$ ed. São Paulo: Editora Unesp, 2012.

RAFFESTIN, Claude. Por uma geografia do poder. São Paulo. Ática, 1993.

RIBAS, Alexandre Domingues; SPOSITO, Eliseu Savério; SAQUET, Marcos Aurélio. Território e desenvolvimento: diferentes abordagens. Francisco Beltrão: Unioeste, 2004.

SANTOS, Milton. A urbanização brasileira. 5ª ed. São Paulo: Edusp, 2008.

SCHNEIDER, J. Elmo. O cooperativismo agrícola na dinâmica social do desenvolvimento periférico dependente: o caso brasileiro. In: LOUREIRO, M. Rita (Org.). Cooperativas agrícolas e capitalismo no Brasil. São Paulo: Cortez, 1981.

SCHLOSSER, Marli Terezinha Szumilo. Rádio, consensos e dissensos: o reverso do discurso e a crise da especialização agrícola (extremo oeste do Paraná). Presidente Prudente, 2005. 259p.

SINGER, Paul. O capitalismo: Sua evolução, sua lógica e sua dinâmica. 6a ed. São Paulo: Moderna, 1991.

SKRZYPCZAK, Valdir. A educação/qualificação dos trabalhadores do campo e da cidade na lógica do capital agroindustrial, na cidade de Xaxim (SC). 2013, 148f. Dissertação (Mestrado em Geografia). Programa de Pós-Graduação em Geografia. Unioeste. Francisco Beltrão - PR.

SKRZYPCZAK, Valdir. Entrevista realizada com N. P. F., camponês integrado da indústria Diplomata de Xaxim (SC). Xaxim, 21 de out. de 2012.

TESTA, Vilson M. et al. O desenvolvimento sustentável do Oeste Catarinense: proposta para discussão. Florianópolis: EPAGRI, 1996.

\section{Correspondência:}

Geografia Ensino \& Pesquisa, v. 18 n.3, p. $37-54$, set./dez. 2014

O trabalhador do campo e da cidade na lógica do capital agroindustrial: Santa Catarina e Paraná

\section{Marilucia Ben}

E-mail: luciaben15@hotmail.com

Recebido em 29 de abril de 2014.

Revisado pelo autor em 17 de novembro de 2014. 